\title{
The Effectivity of Media Card Utilization towards the Ability in Making Poetry in SDN 3 Parepare
}

\author{
Abdul Halik , Joni Muis ${ }^{2}$, Kamaruddin ${ }^{3}$ \\ \{abdul.halik@unm.ac.id ${ }^{1}$, joni.muis@unm.ac.id ${ }^{2}$, kamaruddin@gmail.com ${ }^{3}$ \} \\ 1,2,3 Universitas Negeri Makassar, Indonesia
}

\begin{abstract}
This research aims to know the view of student's ability in making poetry in SDN 3 Parepare by utilising an effective poetry card media. This kind of research is the quantitative research with the utility of True Experimental Design and the used form is Pretest-Posttest Control Group Design. This research population is all of student's SD Negeri 3 Parepare the academic year of 2018/2019 that amount to 373 students and its sample is the Grade IV amounted to 70 students, consisted of 35 men and 35 women. An experiment class and a control class are chosen randomly. The technique of data collecting is utilising an observation and test technique. The data is analysed with a descriptive and inferential analysis by independent t-test to SPSS version 24.0 for Windows. The research result shows that the utilization of learning media poetry card in the learning of Bahasa Indonesia on Pantun (poetry) course is very effective with a highly satisfied output. This has proven on the student's ability in making the poetry in the learning of Bahasa Indonesia. Before the utilization of the learning media poetry card, the student's grade are generally in a low category. But after the utilization of the learning media poetry card in the experiment class, the student's ability in making the poetry is more increase with in a high category, and the control class in general, the ability in making the poetry is in a low category. Therefore, the utilization of the learning media poetry card in the poetry learning is very effective towards the student's ability in making the poetry in SDN 3 Parepare. This is shown by seeing the student's ability in making poetry more increase with the utilization of media poetry card as used by the researcher, compared with the student's ability in making poetry without the utilization of media poetry card.
\end{abstract}

Keywords: poetry, media card

\section{Introduction}

Human is a social being who interconnected with each other. To make a good relationship with others is supported by good communication as well. Indeed, it is used various languages, either oral, written, or sign language. Inappropriate language usage has often given rise to a misunderstanding or another interpretation between a giver and receiver. The misunderstanding in defining a delivered meaning in communicating has fatally impact to the social life, either in the family, school, or social community.

In education, language has a big role in the student's intellectual, social, and emotional development, because all courses that has taught in the educational world is unseparated from good and right language usage. Therefore, language constitutes a success-support to learning all disciplines that taught in the educational world. If the language usage is less inappropriate 
or difficult to be understand by the receiver, the students, then the lesson output cannot be achieve from what is expected indeed.

This lesson of Bahasa Indonesia is not an easy lesson for student although it has used in every day by student to communicating. This is shown from the result of Bahasa Indonesia lesson in the elementary school that unsatisfied. The meant problem is shown from the test result as one of success measurement of Bahasa Indonesia lesson.

The lesson of Bahasa Indonesia is one of the courses that taught in the school aimed "agar siswa mampu berkomunikasi dengan baik dengan menggunakan Bahasa Indonesia yang baik dan benar dan mampu menghargaihasil karya cipta bangsa Indonesia sendiri (to the student can communicate as well with Bahasa Indonesia in good and right and can appreciate the work of Indonesian itself'[1]. One of the subject matter of Bahasa Indonesia that taught in the school in unsatisfied result is the lesson of Pantun (poetry) in the elementary school. This is shown from the result of observation and interview with the Grade IV student, from four schools in Parepare, from four sub-districts, including SDN 3 Parepare. Almost all of students state that the lesson in making poetry is the difficult lesson. There is also student who reveal that listening read poetry is very engrossed, especially if it has reverberated.

The student's confession shows that student basically likes poetry but cannot make poetry and less understands about its which constituted an ancestor heritage. This is annunciated because of teacher in general teaching poetry to only fulfill his lesson program without noticing student's interest on the poetry lesson. The teacher in teaching poetry not uses a media which accompany student in order to quickly understand and comprehend about a way to make poetry.

Based on the observation result that has conducted on June 18, 2019, in the students of SDN 3 Parepare, from the test result of Bahasa Indonesia lesson, especially in the ability in making poetry, is below from KKM grade of 75 . From the interview result with class-teacher states that the teacher's tendency in teaching poetry is just theoretically. Teacher seldom uses media to assist students to understand the subject matter and to increase their ability in making poetry. Besides, student's involvement in the learning process is still very less. The student's involvement is more about answering only the exercise questions.

The lack of teacher's creativity to developing the learning process, especially an utilization of learning media, becomes a trigger of the student's low ability in making poetry. Necessarily, teacher should try to self-develop in increasing his professional task, including the learning media utilization. The media utilization to give a lesson for students has various utilities as stated that media education has the utility as follows: (1) clarifying a presentation as not overly verbal (merely written or oral); (2) dealing with a space, time, and senses limitation; (3) by using media education, precisely and variably, can address the student's passivity [2]. Based on the student's very low ability in making poetry in the Grade IV of SDN 3 Parepare, need to conducted a research of their low ability in making poetry, particularly from the learning media that has used by the teacher.

According to the fact above, researcher intends to examine the effectivity of media card utilization towards student's ability in making poetry in SDN 3 Parepare. This research aims to know what there is an effect of media card utilization towards student's ability in making poetry in SDN 3 Parepare.

\section{Methods}

This research uses an experimental research with the method of True Experimental Design. Said that the true experimental because of this design, researcher can control the way 
of experiment. Thereby, the internal validity can become high. The main characteristic of true experimental is that the used sample for experiment or as a control group is randomly chosen from certain population. Thus, its characteristic is a presence of the control group and sample that is randomly chosen.

There are two groups on this design which are randomly chosen, then given a pre-test to know an early condition about the difference between experiment group and control group. This research uses the pre-test and post-test control group design which is a form of true experiment method. In this research, there are two variables: independent variable and dependent variable. Its independent variable is the media card utilization, whereas its dependent variable is the ability in making poetry.

The operational definition of variables consist of the media card utilization and the student's ability in making poetry. The media card utilization is an activity which conducts in the poetry lesson by using several cards that have a poetry sentence, consisting of an addition sentence and body sentence. In usage, the student is distributed the cards to sticking on a carton which has provided to forming one couplet of poetry. As for the steps of poetry card utilization as follows: (1) a short explanation about the poetry requirements; (2) forming the group; (3) each group setting the poetry card to form the poetry; (4) checking each group's righteousness; (5) each group resetting the unrighteous poetry card in sentence; (6) checking each group's righteousness; (7) each group completing the poetry in which each poetry is merely the addition and body; (8) checking the righteousness of poetry arrangement; (9) each group making the poetry; and (10) each group reading the made poetry in the front of other groups. The student's ability in making poetry is a capability of each student in setting the poetry by noticing the poetry requirements. As for the steps of the poetry as follows: (1) determining the poetry requirements; (2) editing the poetry; and (3) making the poetry accordance with the four requirements of poetry.

Population on this research is all students of SDN 3 Parepare, the school year of 2018/2019, that consist of 373 students. The data collection of this research uses two methods, namely test and observation. The test implementation on this research is meant to measure the ability in making poetry. The used test is a description test, consisting of 15 questions (enclosed), each question has 4-score. The test is conducted twice, namely pre-test and posttest. Pre-test is conducted before giving a treatment in order to know the student's early thinking ability in the experiment and control class. Post-test is conducted after a treatment, namely the media card utilization in the experiment class, whereas the control class is not given a treatment, as this test aims to know an enhancement of student's ability in making poetry by comparing the result of pre-test. Observation is conducted to see how the learning process is running, what activities that are conducted of student during the lesson; and how the overview of lesson implementation by using the media card. This observation uses an observation manual to record the things that are considered important about the activity implementation.

The obtained data from the sample of research overview constitutes a quantitative data. It is analyzed with two kinds of analysis statistic technique, namely descriptive analysis and inferential analysis.

\section{Discussion}

The research is conducted in SDN 3 Parepare to examine the effectivity of media poetry card utilization towards the ability in making poetry of student. While, the research subject of the Grade IV in the second semester on the school year of 2018/2019 by 35 students as control class and 35 students as experiment class, that each class has student's almost same 
characteristic, meant that either control class or experiment class respectively consist of the student in low, medium ability. Each of control class and experiment class is given pre-test on Sunday, June 22, 2019, to know the student's early ability before given learning about the media poetry card utilization. After giving pre-test on each class, either control class or experiment class, the result is examined by using a validity test, and question reliability. The amount of questions have been validity as many as 15 numbers. After conducting pre-test in the control class and experiment class as thrice and each treatment is conducted in 2 x 35 minutes.

The result of this research is obtained from two kinds of instrument, namely the test of student's ability in making poetry and observation. The obtained data through test constitute the pre-test and post-test of experiment and control class. The student's ability in making poetry is categorized as three categories. Namely high, medium, and low.

Before conducting the learning by using media poetry card is previously conducted the pre-test. It aims to know the student's early ability without affected the learning with used media. After completed giving treatment in the experiment class, the post-test is given to the experiment class amounted to 35 students and the control class amounted to 35 students. The post-test result shows a difference ability in making poetry significantly, from both class.

The hypothesis test is examined with Independent Sample T-Test to know the effectivity of media poetry card utilization towards the ability in making poetry in SDN 3 Parepare. The following is explanation about $\mathrm{H} 0$ and $\mathrm{H} 1 . \mathrm{H} 0=$ There is no a difference effect in the student's ability in making poetry of experiment class and control class. $\mathrm{H} 1=$ There is a difference effect in the student's ability in making poetry of experiment class and control class.

The decision making is based on the obtained result of T-Test, namely if it is sig<0,05, then $\mathrm{H} 1$ has accepted and $\mathrm{H} 0$ has rejected. If it is $\mathrm{sig}>0,05$, then $\mathrm{H} 0$ has accepted and $\mathrm{H} 1$ has rejected. The decision making and concluding towards the hypothesis test is conducted in a significance level of $5 \%(0,05)$.

Accordance with the analysis of research result, the media poetry card utilization is very effective towards the ability in making poetry in SDN 3 Parepare, compared with the untaught students of media poetry card. The learning media constitutes of crucial component in education to support the effectivity and efficiency of teaching and learning process [3]. The learning media can be meant as a method or technique by using tool or material in order to give an understanding for student in the teaching and learning process. The fact shows that the usage of media poetry card will give rise to ability in making better poetry, compared with student who is taught without media poetry card in the learning of Bahasa Indonesia. This has proven with an enhancement of student's ability in making poetry in average. The student who is taught with media poetry card, his/her study result is higher than the student who is taught without media poetry card. This has proven by frequency distribution, in the experiment class,, the ability in making poetry is held in medium, high, and very high category, and just two students who is held in low category. Whereas in the control class, there is no held in very high category, just six students in high and medium category, and 27 students in low and very low category.

Based on the researcher's observation during the teaching and learning process in the Grade IV of SDN 3 Parepare, the utilization of media poetry card is very successful and student more enthusiastic to leaning. Whereas, the student's ability in making poetry has categorized in successful and can make poetry. The benefit of learning media in the student's learning process, namely a) the learning will more interest the student's attention thus it can give rise to learning motivation; b) the learning material will more clear of its meaning thus it can be more understand by student to enabling his/her to master and achieve the output; c) the learning method will be more variable, not merely verbal communication through the words narrative by teacher, thus student is not bored and teacher is not out of power, moreover if teacher teach in 
every hour of lessons; and d) students can do more learning activities because not just hear teacher's description, but also another activities, such as observing, doing, demonstrating, portraying, etc [4].

The usage of media poetry card makes students of experiment class enthusiastic to learning because this media is interesting, a new thing for students and easy to completing question, thus students can make the poetry because of the media poetry card utilization. As well as for the teacher by using media as well, teacher not anymore becomes a main resource of learning to the students and no more need to explain all of subject matters because of the media poetry card utilization. In the learning process, researcher is more freely to act and notice the students to completing the task of exercise and to helping students in a difficulty of learning, because the other students completing their task with the media poetry card.

By the description above, can be concluded that the media poetry card utilization in poetry learning in the Grade IV of SDN 3 Parepare is very effective and enhances the student's ability in making poetry, compared with the poetry learning without using the media poetry card, like used by researcher.

\section{Conclusion}

Based on problem formulation, the results and discussion of research has obtained that the calculation result of Levene's Test analysis can be seen its significance grade equal to 0.932 and if it is compared with the manual of decision making, then it has seen that the number of 0,932 is more bigger than 0,05 meant that $\mathrm{H} 0$ is accepted (the data is homogenate) and $\mathrm{H} 1$ is rejected. Accordingly, the used manual to further analyze is the significance grade of t-test that is held in the line of Equal Variances Assumed. The significance grade of t-test in the line of Equal Variances Assumed equals to 0,000 . Because the significance 0,000 is smaller than 0,05 $(0,000<0,05)$, then $\mathrm{H} 1$ is accepted and $\mathrm{H} 0$ is rejected. From the result of hypothesis examination by using Independent Sample T-Test, can be concluded that there is the higher difference towards the ability in making poetry taught by using the media poetry card with the student's ability in making poetry without using the media poetry card. Hence, it can be concluded that the poetry learning in the lesson of Bahasa Indonesia, Grade IV of SDN 3 Parepare, by using the media poetry card is very successful compared with the taught student without using the media poetry card.

\section{References}

[1] Darmadi K, Bahasa Indonesia Untuk SD dan MI Kelas IV. Jakarta: Pusat Pembukuan Departemen Pendidikan Nasional, 2008.

[2] Sadiman, Arief. Rahardjo, dan R. Haryono, Media Pendidikan Pengertian, Pengembangan dan Pemanfaatannya. Jakarta: CV Rajawali, 1990.

[3] Rahman dan Arif M, Kesalahan-Kesalahan Guru Saat Mengajar. Yogyakarta: laksana, 2013.

[4] Arsyad, Azhar, dan Asfah Rahman, Media Pembelajaran. Jakarta: PT Rajagrafindo Persada, 2014.

[5] Arikunto, S. Dasar-Dasar Evaluasi Pendidikan. Jakarta: Bumi Aksara, 2006.

[6] Depdiknas, Kurikulum Tingkat Satuan Pendidikan. Jakarta : Depdiknas, 2006 
[7] Haerini, E. Model Pembelajaran Pikat Alami Namai Tunjukkan dan Ulangi Untuk Meningkatkan Hasil Belajar Siswa dalam Menulis Pantun. Jurnal Universitas Pendidikan Indonesia (online). (www.repository.upi.edu, diakses 7 Agustus 2019).2013.

[8] Ganie, Noor. T. Buku Induk Bahasa Indonesia. Yogyakarta: Araska. 2015

[9] Indriyana, dkk, Pintar Bahasa Indonesia Super Lengkap. Yokyakarta. Indonesia Tera, 2015.

[10] Kosasih, E. Apresiasi Sastra Indonesia. Jakarta: Nobel Edumedia, 2008

[11] Poerwadarminta W.J.S. Kamus Umum Bahasa Indonesia. Jakarta: PT Balai Pustaka (Persero). 2003.

[12] Prang, Anneke M.W. Mencermati Bahasa Indonesia dan Lingkungan Hidup. Jakarta: CV Inti Buku Utama, 1995

[13] Rumy Widyant, Kartu Pantun sebagai Media untuk Meningkatkan Kemampuan Membuat Pantun. PTK tidak dipublikasikan, 2012.

[14] Sadiman, Arief, Media Pendidikan Pengertian, Pengembangan dan Pemanfaatannya Jakarta: PT Rajagrafindo Persada, 2014

[15] Salman, Syukur. Peningkatan Kemampuan Membuat Kalimat Melalui Media Mencari Kata Menyusun Kalimat (Mekameka) siswa Kelas V SD Negeri 71 Parepare. Jurnal Pendidikan Cendekia Kreativitas Guru. 1(10), 55-60.

[16] Soetarno, H. Peristiwa Sastra Melayu Lama. Surakarta: PT Widya Duta Grafika. 2008

[17] Sugiyono. Statistika untuk Penelitian. Bandung: Alfabeta, 2010

[18] _. Metode Penelitian Kuantitatif, Kualitatif dan R \& D. Bandung: Alfabeta, 2014 